\title{
Article \\ Effect of Exogenously Applied Methyl Jasmonate on Yield and Quality of Salt-Stressed Hydroponically Grown Sea Fennel (Crithmum maritimum L.)
}

\author{
M. Hatim Labiad ${ }^{1,2}{ }^{\text {, Almudena Giménez }}{ }^{1}{ }^{(D)}$, Hafise Varol ${ }^{1,3}{ }^{(D)}$, Yüksel Tüzel ${ }^{4}\left(\mathbb{D}\right.$, Catalina Egea-Gilabert ${ }^{1,5}(\mathbb{D}$, \\ Juan A. Fernández ${ }^{1,5}$ (D) and María del Carmen Martínez-Ballesta ${ }^{1,5, *(D)}$
}

1 Ingeniería Agronómica, Universidad Politécnica de Cartagena, Paseo Alfonso XIII 48, 30203 Cartagena, Spain; med.hatim.labiad@gmail.com (M.H.L.); almudena.gimenez@upct.es (A.G.); hafisevarol@gmail.com (H.V.); catalina.egea@upct.es (C.E.-G.); juan.fernandez@upct.es (J.A.F.)

2 Laboratory of Materials, Nanotechnology and Environment, Faculty of Sciences, University Mohamed V Agdal, B. P. 1014 RP, 4 Av. IbnBattouta, Rabat M-10000, Morocco

3 Department of Horticulture, Graduate School of Natural and Applied Science, Ege University, Bornova, Izmir 35100, Turkey

4 Department of Horticulture, Faculty of Agriculture, Ege University, Bornova, Izmir 35100, Turkey; yuksel.tuzel@ege.edu.tr

5 Campus Muralla del Mar, Instituto de Biotecnología Vegetal, Edificio I+D+i, 30202 Cartagena, Spain

* Correspondence: mcarmen.ballesta@upct.es

\section{check for} updates

Citation: Labiad, M.H.; Giménez, A.; Varol, H.; Tüzel, Y.; Egea-Gilabert, C.; Fernández, J.A.; Martínez-Ballesta, M.d.C. Effect of Exogenously Applied Methyl Jasmonate on Yield and Quality of Salt-Stressed Hydroponically Grown Sea Fennel (Crithmum maritimum L.). Agronomy 2021, 11, 1083. https://doi.org/ 10.3390/agronomy11061083

Academic Editor: Marten Sørensen

Received: 25 March 2021

Accepted: 25 May 2021

Published: 27 May 2021

Publisher's Note: MDPI stays neutral with regard to jurisdictional claims in published maps and institutional affiliations.

Copyright: (c) 2021 by the authors. Licensee MDPI, Basel, Switzerland. This article is an open access article distributed under the terms and conditions of the Creative Commons Attribution (CC BY) license (https:// creativecommons.org/licenses/by/ $4.0 /)$.
Abstract: Salt stress is one of the main limiting factors for plant growth and crop yield. Halophytes have been postulated as a new food source since they are able to grow under saline environments and have suitable minerals and bioactive compounds. See fennel Crithmum maritimum L. is a facultative halophyte moderately tolerant to salinity. This study was carried out in order to determine the effect spraying methyl jasmonate (MeJa) on the leaves had on the growth and nutritional quality of $\mathrm{NaCl}$-treated sea fennel plants grown in a hydroponic system. For that, the seedlings were treated with (a) $0.5 \mathrm{mM} \mathrm{MeJa}$, (b) $150 \mathrm{mM} \mathrm{NaCl}$, and (c) $0.5 \mathrm{mM} \mathrm{MeJa}+150 \mathrm{mM} \mathrm{NaCl}$. The results showed that $\mathrm{NaCl}$ reduced the shoot biomass of baby leaf plants, but the addition of MeJa enabled partial recovery. At the same time, when compared with the plants treated only with $\mathrm{NaCl}, \mathrm{MeJa}$ favoured the $\mathrm{Ca}$ and $\mathrm{K}$ uptake and translocation to the leaves of saline-treated plants. However, MeJa did not reduce Na levels. In all treatments, nitrate and nitrite ions were in the range of the acceptable daily intake (ADI) and essential fatty acid content was elevated, although the addition of MeJa to $\mathrm{NaCl}$-treated plants reduced linolenic and linoleic acid contents as compared to the plants treated only with $\mathrm{NaCl}$. Total phenolic compounds were not recovered by MeJa after their decrease by salinity and no differences in antioxidant activity was found between treatments. However, all the plants maintained their antioxidant nutritional properties and increased total flavonoids after MeJa spraying to $\mathrm{NaCl}$-treated plants. These results showed that MeJa spraying alleviated the negative effects of salt stress in C. maritimum grown in floating systems, improving the growth of their edible parts and increasing the total flavonoid and mineral content without affecting the total antioxidant capacity of the plant.

Keywords: antioxidant capacity; methyl jasmonate; minerals; salinity

\section{Introduction}

Fresh fruit and vegetable consumption are recommended by the World Health Organization and the food-based dietary guidelines of countries. This is mainly due to their health promoting components that can prevent chronic diseases as well as several micronutrient deficiencies. However, food-related family lifestyle is one of the factors affecting vegetable consumption [1,2]. Today's urban development, busy lifestyle, and technological societies have contributed to dramatic changes in food demand and consumption [3]. Minimally 
processed baby leaf vegetables are one of the innovations in the food sector offering fresh, nutritious, convenient, diversified and ready-to-eat food products $[4,5]$.

Minimally processed baby leaf vegetables are young leaves in different shapes, colours, and taste harvested at various stages of leaf growth, generally ranging 5 to $12 \mathrm{~cm}$ depending on the species, nutritional quality, shelf-life and final destination of the product [6]. They are rich in terms of natural antioxidants and antimicrobial substances [7] and, when compared with mature leaves, they do not present any nutritional disadvantage [4] and can even be accepted as superior [8]. Furthermore, baby leafy vegetables are important sources of minerals [9] and vitamins [10].

A floating system is particularly appropriate for baby leaf vegetable production since it allows a precise control of plant nutrition and the maximization of yield and quality of the product [11-13], demonstrating that the floating system could be considered an effective tool to improve quality aspects in artichoke and cardoon, improving the production of secondary metabolites through proper management of the salt concentration in the nutrient solution. Furthermore, the production of halophytes plants could be coupled with other cultivation systems. Thus, an integrated multi-trophic aquaculture system is a sustainable industrial solution when the biomass is produced in a balanced manner, because the waste products from fish culture effluent are used as inputs (nutrients) for plants. In this manner, halophytes can contribute to the removal of nutrients dissolved in the water, improving its quality and making it possible to return it to the fish tanks. Moreover, cultivation of halophytes in a floating system could couple with cascade closed systems, which use drained water and nutrients to irrigate another crop. In these systems, because nutrients tend to reach high concentrations in the leachates, increasing the salinity of this water flow, finding a salt-tolerant crop is key to its optimal running [14].

Basil (Ocimum basilicum L.), tatsoi (Brassica rapa L.), endive (Cichorium intibus L.), red and green lettuce (Lactuca sativa L.), rucola (Eruca vesicaria (L.) Cav., Syn. Eruca sativa Mill.), wild rocket (Diplotaxis tenuifolia (L.) DC.), and spinach (Spinacia oleracea L.) are the most common baby leaf vegetables grown commercially [11,15], however, each year new ones are added after being characterised as suitable to use as a baby-leaf vegetable [5].

Sea fennel (Crithmum maritimum L.), also known as rock samphire, is a perennial halophyte and a native plant of coastal ecosystems. It is naturally grown on maritime cliffs and in sand along seacoasts [16]. It is used fresh or cooked, for flavouring purposes, pickled or as a salad ingredient. Sea fennel is also used as a traditional medicine and is even mentioned in the Hippocratic Corpus [17] due to its content of biologically active compounds and essential oils in cosmetics [18]. It also has potential as an insecticide against pests [19].

Sea fennel has gained more recognition recently due to its phytochemicals, which are well recognized for their health-related effects on human nutrition and well-being. Sea fennel is rich in vitamin C [20], minerals, antioxidant activity (in particular, chlorogenic acid), phenol content [21-25], amino acids, flavonoids and essential oil [18,26]. However, studies on cultivation techniques are limited. There has been research conducted on seed germination [27-31], growing media [32] and response to salinity in in vitro conditions [33] or substrate [34] and nutrient solution [35].

Salt tolerance of halophytes differs according to the species. The plant growth and phytochemical pattern of sea fennel is affected by salinity [34], origins of landraces [36,37] and if it is cultivated or wild [16]. For sea fennel, a moderate tolerance to salinity has been reported [34], while high salinity has a negative impact on growth rate and mineral content [35].

Jasmonates (jasmonic acid (JA) and its derivates) are synthesized from $\alpha$-linolenic acid of chloroplast membranes and are important signals in plant stress response [38]. Methyl ester of JA (MeJA) stimulates the production of compounds, which affects plant response to stress. However, MeJa has alleviated salinity stress in many horticultural crops such as strawberry [39], broccoli sprouts [40], and tomato [41]. Additionally, MeJa has 
increased the bioactive compound composition in broccoli and purple tumorous stem mustard sprouts [42,43].

Sea fennel has the potential for cultivation as a baby-leaf vegetable due to its richness in terms of health-promoting compounds and its suitability for cultivation in drought and saline conditions. However, research into cultivation techniques and treatments that could increase the phytochemicals of the plant, as reported by Renna [16], should be carried out in order to attain more knowledge. The general objective of this study was the cultivation of sea fennel as a baby-leaf vegetable in a floating system under greenhouse conditions. The specific goal of this study was to determine the effect of salinity, added to the nutrient solution as $150 \mathrm{mM} \mathrm{NaCl}$, on plant growth, yield and biochemistry, since this halophyte naturally grows in saline environments and its use in aquaponics systems has not been explored. Additionally, the supply of exogenous MeJA, as an elicitor to cope with salt stress and its effect on nutrient compounds in sea fennel plants, was studied.

\section{Material and Methods}

\subsection{Cultivation and Experiment Design}

The experiment was conducted during the fall and spring seasons of 2019 and 2020 at the Technical University of Cartagena, Spain (UPCT; lat. $37^{\circ} 41^{\prime} \mathrm{N}$; long. $0^{\circ} 57^{\prime} \mathrm{W}$ ). After one month of sowing, seedlings of sea fennel were transplanted in polystyrene trays and cultivated in a floating system in an unheated $145 \mathrm{~m}^{2}$ greenhouse covered with thermal polyethylene. Polystyrene trays containing 54 cells were used, with each cell containing two plants. The plant density was around 400 plants/ha. Aeration was provided using a blow pump connected to a perforated pipe trellis positioned at the bottom of each flotation bed and each level of treatment was carried out in a stainless-steel flotation bed of $1.35 \mathrm{~m} \times 1.25 \mathrm{~m} \times 0.2 \mathrm{~m}$ covered with a PVC liner. After one week, the tap water in the beds was replaced with a nutrient solution ( $\mathrm{pH}$ of 5.8 to 5.6 and EC $2.8 \mathrm{dS} / \mathrm{m}$ ), containing the following elements in mol/L: $\mathrm{NO}_{3}{ }^{-}, 7200 ; \mathrm{NH}_{4}{ }^{+}, 4800 ; \mathrm{H}_{2} \mathrm{PO}_{4}{ }^{-}, 2000 ; \mathrm{K}^{+}, 6000$; $\mathrm{Mg}^{2+}, 1500$; and $\mathrm{Ca}^{2+}, 2000$. A commercial mixture of microelements at a concentration of $0.02 \mathrm{~g} \mathrm{~L}^{-1}$ (Nutromix, Biagro S.L., Valencia, Spain) and Fe chelate at a concentration of $0.02 \mathrm{~g} \mathrm{~L}^{-1}$ (Sequestrene, Syngenta AG, Basel, Switzerland) were added to the solution. The $\mathrm{EC}$ and temperature of the nutrient solution were monitored during the growing season using Campbell CS547 sensors (Campbell Scientific Inc., Logan, UT, USA).

Five treatments were considered: control plants (Control1); control plants spraying with Tween $20\left(1 \mathrm{~mL} \mathrm{~L}^{-1}\right)$ in $0,2 \% \mathrm{EtOH}$ (Control2); an addition of $150 \mathrm{mM} \mathrm{NaCl}$ to the nutrient solution $(\mathrm{NaCl})$; spraying with $0.5 \mathrm{mM}$ methyl jasmonate (MeJa); and $150 \mathrm{mM}$ $\mathrm{NaCl}+0.5 \mathrm{mM}$ MeJa $\left(\mathrm{NaCl}+\right.$ MeJa). MeJa was diluted in Tween $201 \mathrm{~mL} \mathrm{~L}^{-1}$ in $0.2 \% \mathrm{EtOH}$ in order to facilitate MeJa leaf penetration. $\mathrm{NaCl}$ was added to the nutrient solution after 1 month of transplanting, whereas an amount of $100 \mathrm{~mL}$ of MeJa, prepared as described above, was sprayed onto the leaves three times every 10 days. The initial addition was 14 days after the $\mathrm{NaCl}$ treatment. The nutrient solution was replaced weekly, and the $\mathrm{pH}$ measured every three days and adjusted to 6.5 by adding sulphuric acid. A total of two replicates (trays) per treatment were placed in a random distribution in the greenhouse floating system, and, at harvest, a total of 10 plants per replicate were taken. The shoot and roots were separated for measurements and kept in $\mathrm{N}_{2}$ liquid for subsequent lyophilisation. The yield and quality analysis, fresh and dry weights of shoots, root growth parameters, chlorophyll and carotenoids, content of fatty acids, total phenolics content, total flavonoids content, and antioxidant capacity were measured.

For determining chlorophylls, total flavonoids, and phenolic content and antioxidant activity, a methanolic extract was obtained with $50 \mathrm{mg}$ of lyophilized sample in $1.5 \mathrm{~mL}$ of methanol in a $2 \mathrm{~mL}$ Eppendorf tube. It was then vortexed and incubated overnight at $4{ }^{\circ} \mathrm{C}$. After incubation, it was centrifuged at $16,000 \times g$ for $5 \mathrm{~min}$ at $4{ }^{\circ} \mathrm{C}$. The supernatant was used as methanolic extract for analysis. 


\subsection{Fresh, Dry Weights of Shoots and Root Growth Parameters}

The fresh weight (FW) of shoots was measured on a scale (Model: RADWAG PS $4500 / C 2$ ) with an accuracy level of $0.0001 \mathrm{~g}$. The dry weight (DW) of shoots was determined by drying in an oven at $60^{\circ} \mathrm{C}$ until constant weight was attained. The shoot hydric content was calculated as the difference between FW and DW referred to DW.

Root length $(\mathrm{cm})$, surface area $\left(\mathrm{cm}^{2}\right)$, and average diameter $(\mathrm{mm})$ of all primary and secondary roots and root volume $\left(\mathrm{cm}^{3}\right)$ parameters were measured using a Winrhizo LA 1600 root counter (Regent Inc., Quebec, QC, Canada).

\subsection{Mineral Analysis}

Anions and cations were extracted from the six samples per treatment and replicate. For that, $0.2 \mathrm{~g}$ of $C$. maritimun dry leaf was used and $50 \mathrm{~mL}$ of distilled water was added. Then, the tubes were shaken in an orbital shaker (Stuart SSL1, Stone, UK) for $45 \mathrm{~min}$ at $110 \mathrm{rpm}$ at $50^{\circ} \mathrm{C}$.

The ion content was quantified by ion chromatography using a Metrosep A SUPP 5 column (Metrohm AG, Zofingen, Switzerland) with a flow rate of $0.7 \mathrm{~mL} \mathrm{~min}{ }^{-1}$ for anions and a Metrosep C 2-250 column (Metrohm AG, Zofingen, Switzerland) with a flow rate of $1.0 \mathrm{~mL} \mathrm{~min}^{-1}$ for cations [44].

\subsection{Fatty Acids}

Fatty acid methyl esters (FAME) were identified following O'Fallon et al.'s [45] methodology, with some modifications. Briefly, $50 \mathrm{mg}$ of freeze-dried samples were placed into a $16 \mathrm{~mm} \times 100 \mathrm{~mm}$ screw-cap Pyrex culture tube containing $0.7 \mathrm{~mL}$ of $10 \mathrm{~N} \mathrm{KOH}$, $1.0 \mathrm{~mL}$ of C13:0 internal standard ( $0.5 \mathrm{mg}$ of $\mathrm{C} 13: 0 / \mathrm{mL}$ of $\mathrm{MeOH})$, and $5.3 \mathrm{~mL}$ of $\mathrm{MeOH}$. The tubes were incubated in a $55{ }^{\circ} \mathrm{C}$ water bath for $1.5 \mathrm{~h}$ and shaken by hand every $20 \mathrm{~min}$. After cooling in a cold tap water bath, $0.58 \mathrm{~mL}$ of $24 \mathrm{~N} \mathrm{H}_{2} \mathrm{SO}_{4}$ were added. The tubes were mixed by inversion and incubated in a $55^{\circ} \mathrm{C}$ water bath for $1.5 \mathrm{~h}$ with hand-shaking. After cooling below room temperature, $1.5 \mathrm{~mL}$ of hexane was added, and the tubes were vortex-mixed for $5 \mathrm{~min}$. Then, the tubes were centrifuged for $5 \mathrm{~min}$ at $1500 \times \mathrm{g}$ and the extracted hexane layer containing the FAMEs was placed in a vial and stored at $-20^{\circ} \mathrm{C}$ until analysis. A gas chromatography (Agilent $6890 \mathrm{~N}$ ), coupled to an autosampler system (Gerstel MPS2) and mass spectrometry detector (Agilent 5975), was used for the fatty acid composition of the FAME, using a Supelco SP-2560 $(100 \mathrm{~m} \times 0.25 \mathrm{~mm} \times 0.2 \mu \mathrm{L})$ capillary column with a flame ionization detector (FID). The gas carrier $\left(20 \mathrm{~cm} \mathrm{~s}^{-1}\right)$ and a temperature program of $140{ }^{\circ} \mathrm{C}$ during $5 \mathrm{~min}, 140-240{ }^{\circ} \mathrm{C}$ at $4{ }^{\circ} \mathrm{C} \mathrm{min}-1,240{ }^{\circ} \mathrm{C}$ during $30 \mathrm{~min}$ and finally $140-240{ }^{\circ} \mathrm{C}$ at $4{ }^{\circ} \mathrm{C} \mathrm{min}^{-1}$. Both the injector and detector temperature were $260^{\circ} \mathrm{C}$. Methyl esters pattern (Sigma-Aldrich 47885-U, Merck KGaA, Darmstadt, Germany) was used for identification.

The double bond index (DBI) was calculated as the unsaturated fatty acid per number of double bonds.

\subsection{Chlorophylls and Carotenoids}

Methanol extracts (50 $\mu \mathrm{L})$, obtained as reported in Section 2.1, were used to measure chlorophyll and carotenoids. Spectrophotometric measurements of total carotenoids and chlorophyll content were carried out by measuring the absorbances at 652, 665 and $470 \mathrm{~nm}$, which were measured in a UV-visible spectrophotometer (8453, Hewlett Packard, Columbia, SC, USA). The equations developed by Lichtenthaler and Buschmann [46] were used to determine the individual levels of chlorophyll a, chlorophyll $\mathrm{b}$ and total carotenoids. Total chlorophyll and total carotenoids contents were expressed as $\mathrm{mg} \mathrm{kg}^{-1} \mathrm{DW}$. Five plants of each replicate were analysed.

\subsection{Total Flavonoids Content}

Total flavonoid content was determined as described by Meda et al. [47]. Methanolextracts $(50 \mu \mathrm{L})$, obtained as reported in Section $2.1, \mathrm{MeOH}(300 \mu \mathrm{L})$ and $\mathrm{AlCl}_{3}(2 \%)(350 \mu \mathrm{L})$ 
were mixed and incubated for $20 \mathrm{~min}$ at room temperature in darkness and the absorbance was measured at $430 \mathrm{~nm}$. The results were expressed in mg Rutin per kg of FW. Five plants of each replicate were analysed.

\subsection{Total Phenolic Content and Antioxidant Capacity}

The total phenolic content was determined by the Folin-Ciocalteu colorimetric method, according to Everette et al. [48]. Methanol extracts $(50 \mu \mathrm{L})$, obtained as reported in Section 2.1, $\mathrm{H}_{2} \mathrm{O}$ distilled $(790 \mu \mathrm{L})$ and Folin $(50 \mu \mathrm{L})$ were mixed and incubated for $5 \mathrm{~min}$. Then, $150 \mu \mathrm{L}$ of a solution of $\mathrm{Na}_{2} \mathrm{CO}_{3}(20 \%)$ was added. After $2 \mathrm{~h}$ of incubation at room temperature in darkness, the absorbance was measured at $765 \mathrm{~nm}$ using a UV-visible spectrophotometer. The results were expressed in mg gallic acid (GA) per $\mathrm{kg}$ of FW. Each of the three replicates were analysed in triplicate (instrumental replicate).

The antioxidant capacity was evaluated in terms of their free radical-scavenging potential [49], with the modifications as described by Perez-Tortosa et al. [50]. Methanol extracts $(25 \mu \mathrm{L})$ and DPPH $(0.1 \mathrm{mM})(600 \mu \mathrm{L})$ were mixed and incubated for 15-20 min at room temperature in darkness and the absorbance was measured at $517 \mathrm{~nm}$. The results were expressed in $\mathrm{mg}$ DPPH reduced per $\mathrm{kg}$ of FW. Five plants of each replicate were analysed.

\subsection{Statistics}

The data were analysed statistically by Tukey's test, comparing each cultivar individually, using the SPSS 20.0 software package. Significant differences were determined at $p<0.05$.

\section{Results}

\subsection{Biomass and Root Growth Parameters}

The higher shoot FW was observed in Control1 plants without significant differences regarding Control2 (Figure 1). $\mathrm{NaCl}$ treatment reduced the shoot $\mathrm{FW}$ of $\mathrm{C}$. maritimum plants, while MeJa application in saline condition $(\mathrm{NaCl}+\mathrm{MeJa})$ partially recovered the shoot $\mathrm{FW}$ when compared with the only $\mathrm{NaCl}$ addition, without significant differences regarding Control2. The only MeJa treatment caused a reduction in shoot FW as compared to Control1, but not with respect to Control2. Shoot DW projected a similar pattern to shoot FW. As for total plant $\mathrm{DW}, \mathrm{NaCl}$ and $\mathrm{NaCl}+\mathrm{MeJa}$ treatments reached the highest values. Control1 and Control2 values were similar and higher than MeJa treated plants.

Total root length and root surface area were the highest in the $\mathrm{NaCl}$ treatment when compared with the rest of treatments, which did not show significant differences for these parameters (Table 1). Root diameter was not modified after any of the treatment applications. Similarly, root volume was significantly higher in the $\mathrm{NaCl}$ treatment in relation to Control1 and MeJa.

\subsection{Ion Content}

Cations $\left(\mathrm{Mg}^{2+}, \mathrm{Ca}^{2+}, \mathrm{K}^{+}, \mathrm{NH}_{4}^{+}\right.$and $\left.\mathrm{Na}^{+}\right)$and anions $\left(\mathrm{F}^{-}, \mathrm{Cl}^{-}, \mathrm{NO}_{2}, \mathrm{Br}^{-}, \mathrm{NO}_{3}^{-}\right.$, $\mathrm{PO}_{4}{ }^{-}, \mathrm{C}_{2} \mathrm{O}_{4}{ }^{2-}$ ) determined in the leaves of $\mathrm{C}$. maritimum are shown in Tables 2 and 3. Regarding cations, $\mathrm{Mg}^{2+}$ content was higher in $\mathrm{NaCl}+\mathrm{MeJa}$ treated plants compared to those treated with only $\mathrm{NaCl}$, but no significant differences were found between Control1, Control2, MeJa, and $\mathrm{NaCl}+\mathrm{MeJa}$ treatments. $\mathrm{Ca}^{2+}$ content was similar in all treatments with the exception of the $\mathrm{NaCl}$ treatment, where $\mathrm{Ca}^{2+}$ content decreased. $\mathrm{K}^{+}$content was similar in Control1, Control2 and MeJa plants and it decreased in $\mathrm{NaCl}$ treatment. The two MeJa addition treatments increased the $\mathrm{NH}_{4}{ }^{+}$content as compared to the Control1 and Control 2 treatments. No significant differences appeared among them. Finally, $\mathrm{Na}^{+}$was higher in $\mathrm{NaCl}$ and $\mathrm{NaCl}+\mathrm{MeJa}$ treatments compared with Control1, Control2, and MeJa. The K/Na ratio was higher in Control1, Control2, and MeJa treatments than in both $\mathrm{NaCl}$ treatments. However, although the content of $\mathrm{K}^{+}$was higher in $\mathrm{NaCl}+\mathrm{MeJa}$ treated plants 
compared to the $\mathrm{NaCl}$ only addition, no significant differences were found in the $\mathrm{K} / \mathrm{Na}$ ratio between both treatments.
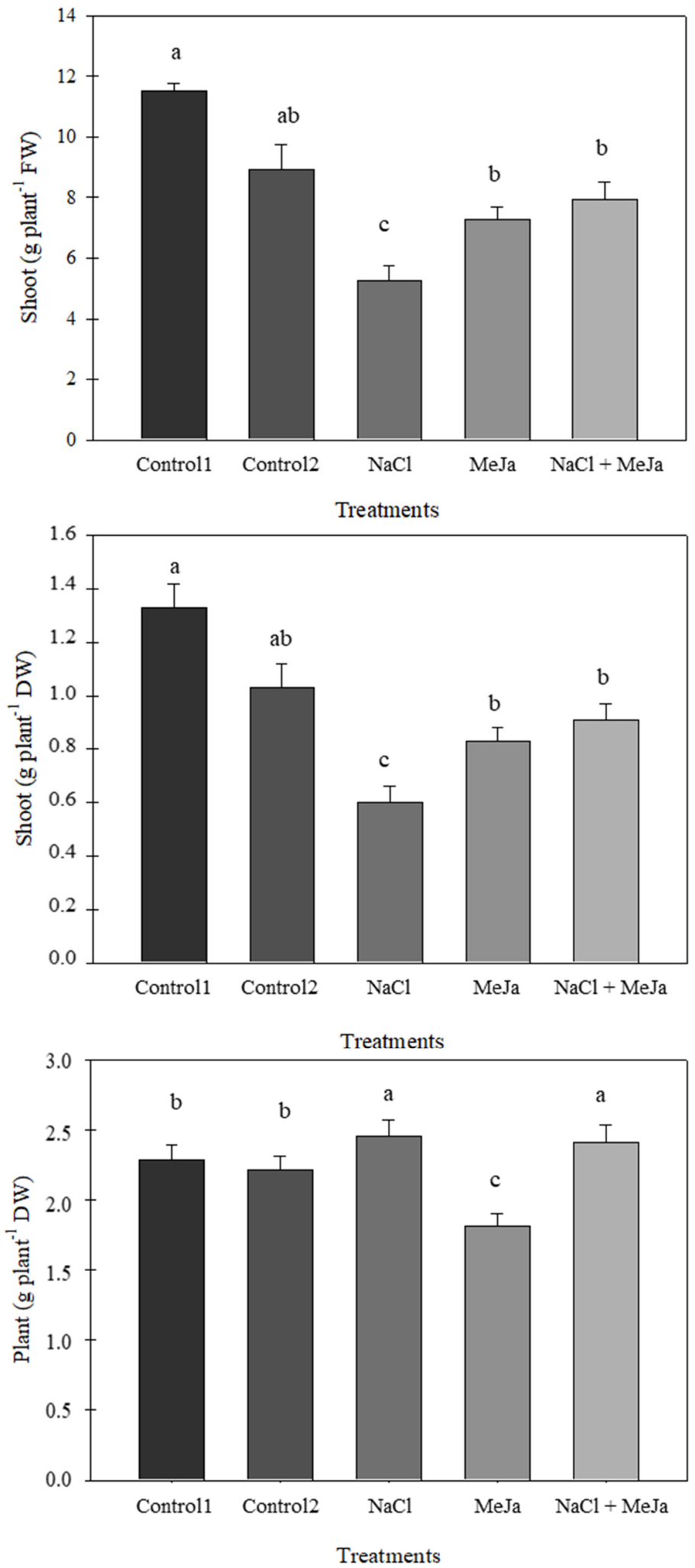

Figure 1. Fresh weight (FW) and dry weight (DW) of the aerial part of C. maritimum plants, and DW (gr plant ${ }^{-1}$ ) of the whole plant, grown under hydroponic conditions with the following treatments: Control1, Control2, NaCl, MeJa, $\mathrm{NaCl}+\mathrm{MeJa},(n=20)$. Different letters $(\mathrm{a}, \mathrm{b}, \mathrm{c})$ indicate significant differences according to Tukey's test $(p<0.05)$. 
Table 1. Root growth parameters (length, surface area, average diameter, and root volume) of C. maritimum plants grown under hydroponic conditions with the following treatments: control1, Control2, $\mathrm{NaCl}, \mathrm{MeJa}, \mathrm{NaCl}+\mathrm{MeJa},(n=20)$. Columns with different letters $(\mathrm{a}, \mathrm{b})$ for each variable differ significantly according to Tukey's test $(p<0.05)$.

\begin{tabular}{ccccc}
\hline Treatments & $\begin{array}{c}\text { Total Length } \\
\mathbf{( c m )}\end{array}$ & Surf Area $\left.\mathbf{( c m}^{\mathbf{2}}\right)$ & Root Dia. $\mathbf{( m m )}$ & $\begin{array}{c}\text { Root Volume } \\
\left(\mathbf{c m}^{\mathbf{3}} \mathbf{)}\right.\end{array}$ \\
\hline Control1 & $222.48 \pm 38.19 \mathrm{~b}$ & $35.46 \pm 5.66 \mathrm{~b}$ & $0.54 \pm 0.04 \mathrm{a}$ & $0.49 \pm 0.08 \mathrm{~b}$ \\
Control2 & $207.84 \pm 29.75 \mathrm{~b}$ & $38.99 \pm 5.98 \mathrm{~b}$ & $0.60 \pm 0.04 \mathrm{a}$ & $0.62 \pm 0.12 \mathrm{ab}$ \\
$\mathrm{NaCl}$ & $347.57 \pm 49.33 \mathrm{a}$ & $65.05 \pm 8.59 \mathrm{a}$ & $0.63 \pm 0.05 \mathrm{a}$ & $1.01 \pm 0.13 \mathrm{a}$ \\
$\mathrm{MeJa}$ & $207.90 \pm 25.61 \mathrm{~b}$ & $33.14 \pm 4.64 \mathrm{~b}$ & $0.50 \pm 0.03 \mathrm{a}$ & $0.46 \pm 0.086 \mathrm{~b}$ \\
$\mathrm{NaCl}+\mathrm{MeJa}$ & $219.14 \pm 37.8 \mathrm{~b}$ & $44.25 \pm 6.69 \mathrm{ab}$ & $0.65 \pm 0.05 \mathrm{a}$ & $0.75 \pm 0.12 \mathrm{ab}$ \\
\hline
\end{tabular}

Table 2. The content of cations $\left(\mathrm{Mg}^{2+}, \mathrm{Ca}^{2+}, \mathrm{K}^{+}, \mathrm{NH}_{4}{ }^{+}, \mathrm{Na}^{+}\right.$and $\mathrm{K} / \mathrm{Na}$ ratio $)\left(\mathrm{mg} \mathrm{kg}^{-1} \mathrm{FW}\right)$ in the leaf tissues of $C$. maritimum under the different treatments (Control1, Control2, $\mathrm{NaCl}, \mathrm{MeJa}, \mathrm{NaCl}+\mathrm{MeJa}),(n=10)$. Columns with different letters $(\mathrm{a}, \mathrm{b}, \mathrm{c})$ for each variable differ significantly according to Tukey's test $(p<0.05)$.

\begin{tabular}{|c|c|c|c|c|c|c|}
\hline Treatment & $\mathrm{Mg}^{2+}$ & $\mathrm{Ca}^{2+}$ & $\mathbf{K}^{+}$ & $\mathrm{NH}_{4}^{+}$ & $\mathrm{Na}^{+}$ & $\mathrm{K} / \mathrm{Na}$ \\
\hline Control1 & $309.00 \pm 6.09 \mathrm{ab}$ & $\begin{array}{c}997.72 \pm \\
10.036 a\end{array}$ & $\begin{array}{c}2411.01 \pm \\
48.78 \mathrm{ab}\end{array}$ & $277.59 \pm 23.13 a$ & $977.27 \pm 70.43 b$ & $2.47 \pm 0.2 \mathrm{a}$ \\
\hline Control2 & $299.25 \pm 20.21 \mathrm{ab}$ & $901.05 \pm 53.26 a$ & $\begin{array}{c}2295.72 \pm \\
125.96 \mathrm{ab}\end{array}$ & $251.19 \pm 14.84 \mathrm{a}$ & $1086.10 \pm 67.04 b$ & $2.11 \pm 0.2 \mathrm{a}$ \\
\hline $\mathrm{NaCl}$ & $255.03 \pm 53.10 b$ & $692.83 \pm 36.78 b$ & $\begin{array}{c}1628.10 \pm \\
113.72 \mathrm{c}\end{array}$ & $\begin{array}{l}384.90 \pm \\
15.00 \mathrm{ab}\end{array}$ & $2698.07 \pm 16.54 a$ & $0.60 \pm 0.1 b$ \\
\hline MeJa & $283.91 \pm 12.15 \mathrm{ab}$ & $926.53 \pm 28.21 a$ & $\begin{array}{c}2901.40 \pm \\
121.81 \mathrm{a}\end{array}$ & $\begin{array}{c}449.18 \pm \\
104.60 \mathrm{~b}\end{array}$ & $1308.48 \pm 51.43 b$ & $2.21 \pm 0.2 \mathrm{a}$ \\
\hline $\mathrm{NaCl}+\mathrm{MeJa}$ & $342.78 \pm 10.98 a$ & $\begin{array}{c}1044.16 \pm \\
88.79 a\end{array}$ & $\begin{array}{c}2006.77 \pm \\
134.36 \mathrm{~b}\end{array}$ & $447.61 \pm 48.50 \mathrm{~b}$ & $2703.18 \pm 44.96 a$ & $0.74 \pm 0.1 b$ \\
\hline
\end{tabular}

Table 3. The content of anions $\left(\mathrm{F}^{-}, \mathrm{Cl}^{-}, \mathrm{NO}_{2}{ }^{-}, \mathrm{Br}^{-}, \mathrm{NO}_{3}{ }^{-}, \mathrm{PO}_{4}{ }^{3-}, \mathrm{C}_{2} \mathrm{O}_{4}{ }^{2-}\right)\left(\mathrm{mg} \mathrm{kg}{ }^{-1} \mathrm{FW}\right)$ in the leaf tissues of $C$. maritimum under the different treatments (Control1, Control2, $\mathrm{NaCl}, \mathrm{MeJa}, \mathrm{NaCl}+\mathrm{MeJa}),(n=10)$. Columns with different letters $(\mathrm{a}, \mathrm{b}, \mathrm{c})$ for each variable differ significantly according to Tukey's test $(p<0.05)$.

\begin{tabular}{|c|c|c|c|c|c|c|c|}
\hline Treatment & $\mathbf{F}^{-}$ & $\mathrm{Cl}^{-}$ & $\mathrm{NO}_{2}{ }^{-}$ & $\mathrm{Br}^{-}$ & $\mathrm{NO}_{3}{ }^{-}$ & $\mathrm{PO}_{4}{ }^{3-}$ & $\mathrm{C}_{2} \mathrm{O}_{4}{ }^{2-}$ \\
\hline Control1 & $20.88 \pm 0.97 a$ & $\begin{array}{c}2285.63 \pm \\
162.74 \mathrm{~b}\end{array}$ & $\begin{array}{c}963.25 \pm \\
8.94 \mathrm{a}\end{array}$ & $\begin{array}{c}109.62 \pm \\
0.90 \mathrm{~b}\end{array}$ & $\begin{array}{c}296.95 \pm \\
23.32 \mathrm{a}\end{array}$ & $\begin{array}{c}944.38 \pm \\
25.93 c\end{array}$ & $\begin{array}{c}116.46 \pm \\
4.42 \mathrm{~b}\end{array}$ \\
\hline Control2 & $25.83 \pm 4.56 a$ & $\begin{array}{c}2515.93 \pm \\
104.79 b\end{array}$ & $\begin{array}{c}845.95 \pm \\
36.81 \mathrm{a}\end{array}$ & $\begin{array}{c}105.87 \pm \\
0.86 \mathrm{~b}\end{array}$ & $\begin{array}{c}229.12 \pm \\
8.13 a\end{array}$ & $\begin{array}{c}911.26 \pm \\
25.64 \mathrm{c}\end{array}$ & $\begin{array}{c}108.28 \pm \\
1.11 b\end{array}$ \\
\hline $\mathrm{NaCl}$ & $21.71 \pm 0.87 a$ & $\begin{array}{c}4385.71 \pm \\
31.93 \mathrm{a}\end{array}$ & $\begin{array}{c}453.87 \pm \\
90.22 \mathrm{~b}\end{array}$ & $\begin{array}{c}109.38 \pm \\
0.67 \mathrm{~b}\end{array}$ & $\begin{array}{c}255.84 \pm \\
9.10 \mathrm{a}\end{array}$ & $\begin{array}{c}940.02 \pm \\
14.36 \mathrm{c}\end{array}$ & $\begin{array}{c}134.28 \pm \\
1.89 a\end{array}$ \\
\hline MeJa & $25.83 \pm 1.25 a$ & $\begin{array}{c}2840.38 \pm \\
4.00 \mathrm{~b}\end{array}$ & $\begin{array}{c}970.44 \pm \\
12.22 \mathrm{a}\end{array}$ & $\begin{array}{c}120.20 \pm \\
1.40 \mathrm{a}\end{array}$ & $\begin{array}{c}276.49 \pm \\
1.66 \mathrm{a}\end{array}$ & $\begin{array}{c}1082.62 \pm \\
23.03 \mathrm{~b}\end{array}$ & $\begin{array}{c}128.90 \pm \\
7.94 \mathrm{ab}\end{array}$ \\
\hline $\mathrm{NaCl}+\mathrm{MeJa}$ & $24.81 \pm 0.75 a$ & $\begin{array}{c}4986.10 \pm \\
39.67 \mathrm{a}\end{array}$ & $\begin{array}{c}954.57 \pm \\
15.37 \mathrm{a}\end{array}$ & $\begin{array}{c}132.47 \pm \\
0.81 \mathrm{a}\end{array}$ & $\begin{array}{c}292.59 \pm \\
0.74 \mathrm{a}\end{array}$ & $\begin{array}{c}1278.91 \pm \\
20.64 \mathrm{a}\end{array}$ & $\begin{array}{c}126.25 \pm \\
6.58 \mathrm{ab}\end{array}$ \\
\hline
\end{tabular}

A high correlation between shoot $\mathrm{Na}^{+}$and leaf hydric content was observed (Figure 2). Regarding anions, $\mathrm{F}^{-}$and $\mathrm{NO}_{3}{ }^{-}$content did not show significant differences between treatments in the leaves of $C$. maritimum (Table 3). $\mathrm{Cl}^{-}$content was higher in the $\mathrm{NaCl}$ and $\mathrm{NaCl}+\mathrm{MeJa}$ treated plants compared with the rest of treatments. $\mathrm{NO}_{2}{ }^{-}$content only decreased in $\mathrm{NaCl}^{-}$treated plants, and $\mathrm{Br}^{-}$content increased in plants treated with both MeJa treatments in comparison to the rest. $\mathrm{PO}_{4}{ }^{3-}$ content was enhanced in $\mathrm{MeJa}$ and $\mathrm{NaCl}+\mathrm{MeJa}$ treated plants, with the increase observed as being higher in plants treated with $\mathrm{NaCl}+\mathrm{MeJa}$. Finally, $\mathrm{C}_{2} \mathrm{O}_{4}{ }^{2-}$ content was higher in $\mathrm{NaCl}$ treatment and similar in both control treatments. 


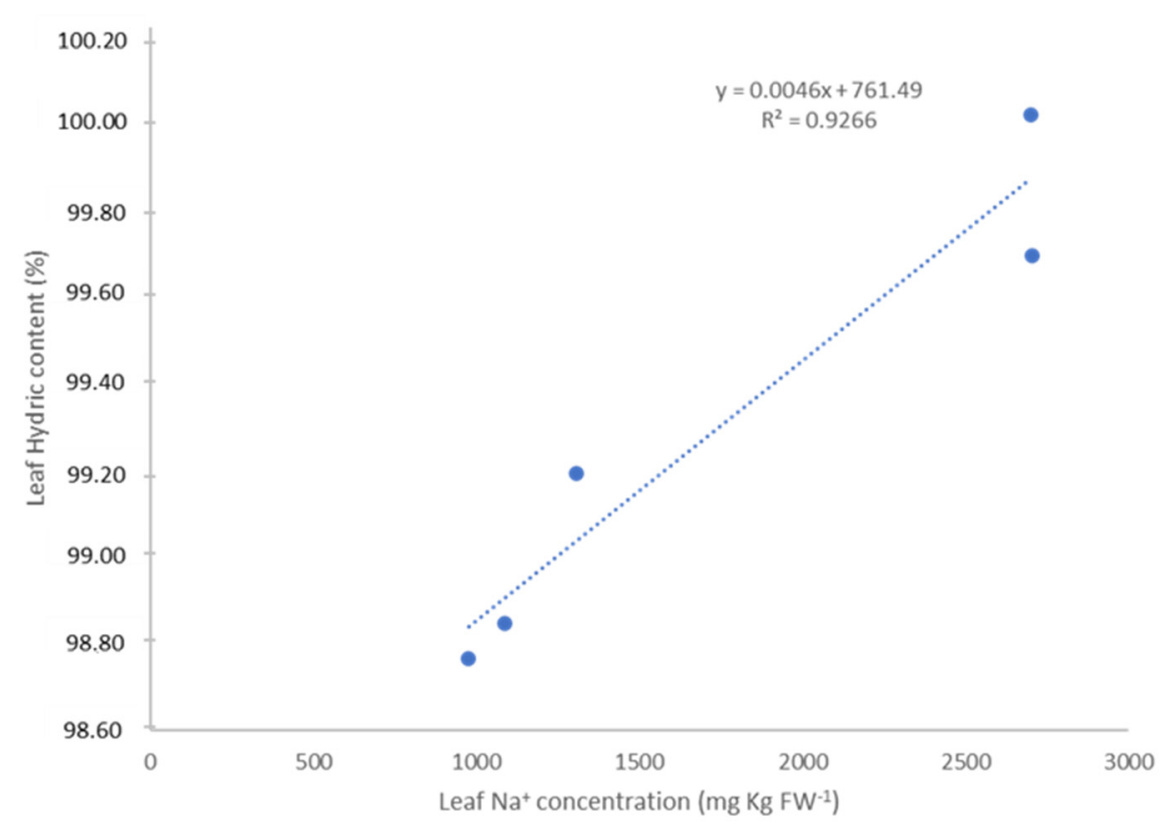

Figure 2. Correlation between leaf hydric content and leaf $\mathrm{Na}^{+}$concentration.

\subsection{Fatty Acids}

The fatty acids analysis revealed that the C. maritimum leaves showed an increase in the unsaturated and saturated fatty acids in the $\mathrm{NaCl}$ treatment (Table 4). Among unsaturated acids, the increases were observed in oleic and linoleic acids, whereas $\mathrm{NaCl}$ treatment did not affect the content of linolenic acid regarding Control1. This fact produced an increase in the double bond index (DBI). The addition of MeJa to NaCl-treated plants had no significant effect on the content of individual fatty acids regarding Control1, with the exception of the saturated lignocerate acid that was not detected, but the total fatty acids were lower than in the Control2 and $\mathrm{NaCl}$-treated plants. However, considering the percentage of individual fatty acids observed in total (Table 5), the MeJa application in $\mathrm{NaCl}$ conditions increased the percentage of oleic and linolenic acids (Omega 3 acids) with regard to the rest of treatments and reduced the linoleic acid content. The MeJa sprayed plants showed similar fatty acid content during the $\mathrm{NaCl}$ treatment when compared to Control and MeJa treated plants, but the DBI was lower than that of the Control1 plants.

\subsection{Total Phenolic Compounds and Total Flavonoids}

Total phenolic compounds determined in the leaves of $C$. maritimum plants are shown in Table 6. The content of total phenolic compounds was similar in Control1, Control2 and MeJa treated plants, but it increased in $\mathrm{NaCl}$ and $\mathrm{NaCl}+$ MeJa treated plants. Total flavonoids increased in $\mathrm{NaCl}, \mathrm{MeJa}$, and $\mathrm{NaCl}+\mathrm{MeJa}$ treated plants in comparison to both controls. Finally, no significant differences were found in the total antioxidant capacity between treatments. 
Table 4. The content of fatty acids $\left(\mathrm{mg} \mathrm{gr}^{-1} \mathrm{DW}\right)$ in the leaf tissues of $C$. maritimum under the different treatments (Control1, Control2, $\mathrm{NaCl}, \mathrm{MeJa}, \mathrm{NaCl}+\mathrm{MeJa}),(n=10)$. Rows with different letters $(\mathrm{a}, \mathrm{b}, \mathrm{c})$ for each variable differ significantly according to Tukey's test $(p<0.05)$, n.s means not significative.

\begin{tabular}{|c|c|c|c|c|c|c|}
\hline \multirow[b]{2}{*}{ Fatty Acid (mg gr $\left.{ }^{-1} \mathrm{DW}\right)$} & & \multirow[b]{2}{*}{ Control1 } & \multicolumn{4}{|c|}{ Treatment } \\
\hline & & & Control2 & MeJa & $\mathrm{NaCl}$ & $\mathrm{MeJa}+\mathrm{NaCl}$ \\
\hline \multicolumn{7}{|l|}{$\begin{array}{l}\text { Saturated fatty acid } \\
\text { (SFA) }\end{array}$} \\
\hline Lauric acid & $\mathrm{C} 12: 0$ & - & - & - & $0.09 \pm 0.00 \mathrm{~b}$ & - \\
\hline Myristate acid & C14:0 & $0.07 \pm 0.00 \mathrm{a}$ & $0.12 \pm 0.01 \mathrm{a}$ & $0.11 \pm 0.00 \mathrm{a}$ & $0.17 \pm 0.03 b$ & $0.11 \pm 0.00 \mathrm{a}$ \\
\hline Palmitate acid & $\mathrm{C} 16: 0$ & $1.50 \pm 0.02 \mathrm{a}$ & $1.65 \pm 0.01 \mathrm{a}$ & $1.48 \pm 0.02 \mathrm{a}$ & $2.12 \pm 0.31 b$ & $1.38 \pm 0.00 \mathrm{a}$ \\
\hline Stearate acid & C18:0 & $0.49 \pm 0.04 \mathrm{ab}$ & $0.43 \pm 0.02 \mathrm{a}$ & $0.47 \pm 0.01 \mathrm{ab}$ & $0.58 \pm 0.04 b$ & $0.41 \pm 0.03 a$ \\
\hline Arachidate acid & C20:0 & $0.12 \pm 0.01 \mathrm{a}$ & $0.19 \pm 0.02 b c$ & $0.15 \pm 0.00 \mathrm{ab}$ & $0.33 \pm 0.03 \mathrm{~d}$ & $0.21 \pm 0.02 c$ \\
\hline Behenate acid & $\mathrm{C} 22: 0$ & - & $0.29 \pm 0.00 b$ & $0.17 \pm 0.00 \mathrm{a}$ & $0.30 \pm 0.02 b$ & $0.23 \pm 0.06 \mathrm{ab}$ \\
\hline Lignocerate acid & C24:0 & - & $0.29 \pm 0.00 b$ & $0.23 \pm 0.00 \mathrm{a}$ & $0.26 \pm 0.00 \mathrm{~b}$ & - \\
\hline $\begin{array}{l}\text { Monounsaturated fatty } \\
\text { acid (MUFA) }\end{array}$ & & & & & & \\
\hline Oleic acid & C18:1 n9 & $0.41 \pm 0.01 \mathrm{a}$ & $0.39 \pm 0.00 \mathrm{a}$ & $0.31 \pm 0.00 \mathrm{a}$ & $0.69 \pm 0.13 b$ & $0.42 \pm 0.03 a$ \\
\hline \multirow{2}{*}{\multicolumn{7}{|c|}{$\begin{array}{c}\text { Polyunsaturated fatty acid } \\
\text { (PUFA) } \\
\text { Omega } 6(\mathrm{w} 6)\end{array}$}} \\
\hline & & & & & & \\
\hline $\begin{array}{l}\text { Linoleic acid. } \\
\text { Omega } 3 \text { (w3) }\end{array}$ & $\mathrm{C} 18: 2 \mathrm{n} 6$ & $8.76 \pm 0.12 \mathrm{a}$ & $10.54 \pm 0.40 \mathrm{ab}$ & $8.90 \pm 0.17 a$ & $12.44 \pm 1.37 \mathrm{~b}$ & $8.70 \pm 0.20 \mathrm{a}$ \\
\hline Linolenic acid & C18:3 n3 & $7.14 \pm 0.32 \mathrm{a}$ & $7.93 \pm 0.04 \mathrm{ab}$ & $6.65 \pm 0.35 a$ & $10.37 \pm 0.223 b$ & $6.13 \pm 0.00 \mathrm{a}$ \\
\hline $\begin{array}{l}\text { DBI (unsaturated fatty acid } \\
x \text { number of double bonds) }\end{array}$ & & $39.35 \pm 2.12 b$ & $44.2 \pm 3.04 \mathrm{ab}$ & $56.68 \pm 3.56 a$ & $38.06 \pm 2.16 b$ & $36.21 \pm 1.98 b$ \\
\hline $\begin{array}{c}\text { w6/w3 } \\
\text { Total }\end{array}$ & & $\begin{array}{c}1.23 \pm 0.07 \text { n.s. } \\
18.53\end{array}$ & $\begin{array}{c}1.33 \pm 0.00 \text { n.s. } \\
21.83\end{array}$ & $\begin{array}{c}1.34 \pm 0.04 \text { n.s. } \\
18.48\end{array}$ & $\begin{array}{c}1.26 \pm 0.15 \text { n.s. } \\
27.29\end{array}$ & $\begin{array}{c}1.42 \pm 0.04 \text { n.s. } \\
17.62\end{array}$ \\
\hline
\end{tabular}

Table 5. Fatty acids content expressed as percentage of the aerial part of $C$. maritimum plants grown under hydroponic conditions with the following treatments: Control1, Control2, $\mathrm{NaCl}, \mathrm{MeJa}, \mathrm{NaCl}+\mathrm{MeJa},(n=6)$.

\begin{tabular}{|c|c|c|c|c|c|c|}
\hline \multirow[b]{2}{*}{ Fatty Acid (\%) } & & \multirow[b]{2}{*}{ Control1 } & \multicolumn{4}{|c|}{ Treatment } \\
\hline & & & Control2 & МeJa & $\mathrm{NaCl}$ & $\mathrm{MeJa}+\mathrm{NaCl}$ \\
\hline \multicolumn{7}{|l|}{$\begin{array}{c}\text { Saturated fatty acid } \\
\text { (SFA) }\end{array}$} \\
\hline Lauric acid & C12:0 & - & - & - & 0.003 & - \\
\hline Myristate acid & C14:0 & 0.38 & 0.55 & 0.59 & 0.62 & 0.62 \\
\hline Palmitate acid & $\mathrm{C} 16: 0$ & 8.11 & 7.55 & 8.01 & 7.77 & 7.84 \\
\hline Stearate acid & C18:0 & 2.65 & 1.96 & 2.54 & 2.12 & 2.33 \\
\hline Arachidate acid & C20:0 & 0.65 & 0.87 & 0.81 & 1.21 & 1.19 \\
\hline Behenate acid & $\mathrm{C} 22: 0$ & - & 1.32 & 0.92 & 1.10 & 1.30 \\
\hline Lignocerate acid & C24:0 & - & 1.32 & 1.24 & 0.95 & - \\
\hline \multicolumn{7}{|c|}{$\begin{array}{l}\text { Monounsaturated fatty } \\
\text { acid (MUFA) }\end{array}$} \\
\hline Oleic acid & C18:1 n9 & 2.21 & 1.78 & 1.68 & 2.53 & 2.38 \\
\hline \multirow{2}{*}{\multicolumn{7}{|c|}{$\begin{array}{c}\text { Polyunsaturated fatty acid } \\
\text { (PUFA) } \\
\text { Omega } 6(\mathrm{w} 6)\end{array}$}} \\
\hline & & & & & & \\
\hline $\begin{array}{l}\text { Linoleic acid } \\
\text { Omega } 3 \text { (w3) }\end{array}$ & C18:2 n6 & 47.37 & 48.28 & 48.18 & 45.04 & 49.46 \\
\hline Linolenic acid & C18:3 n3 & 38.61 & 36.32 & 36.00 & 38.04 & 34.85 \\
\hline
\end{tabular}


Table 6. The content of total phenolic compounds (mg GA kg-1 FW), total flavonoids (mg Rutin $\mathrm{kg}^{-1} \mathrm{FW}$ ), and antioxidant capacity (mg DPPH reduced $\mathrm{kg}^{-1} \mathrm{FW}$ ) in the leaf tissues of $C$. maritimum under the different treatments (Control1, Control2, $\mathrm{NaCl}, \mathrm{MeJa}, \mathrm{NaCl}+\mathrm{MeJa}),(n=10)$. Columns with different letters $(\mathrm{a}, \mathrm{b})$ for each variable differ significantly according to Tukey's test $(p<0.05)$.

\begin{tabular}{|c|c|c|c|}
\hline Treatments & $\begin{array}{c}\text { Total Phenolic } \\
\text { compounds } \\
\text { (mg GA kg }{ }^{-1} \text { FW) }\end{array}$ & $\begin{array}{c}\text { Total Flavonoids } \\
\text { (mg Rutin kg } \text { k' }^{-1} \text { FW) }\end{array}$ & $\begin{array}{c}\text { Antioxidant } \\
\text { Capacity } \\
\text { (mg DPPH } \text { Deduced }_{\text {m }} \\
\text { kg }^{-1} \text { FW) }\end{array}$ \\
\hline Control1 & $891.79 \pm 15.79 a$ & $1965.41 \pm 47.17 b$ & $113.64 \pm 7.17 \mathrm{a}$ \\
\hline Control2 & $883.09 \pm 8.11 \mathrm{a}$ & $1968.39 \pm 6.30 b$ & $110.85 \pm 5.47 \mathrm{a}$ \\
\hline $\mathrm{NaCl}$ & $833.53 \pm 9.42 b$ & $2167.24 \pm 22.09 a$ & $109.92 \pm 5.84 a$ \\
\hline MeJa & $901.50 \pm 9.71 \mathrm{a}$ & $2186.94 \pm 597 a$ & $108.81 \pm 1.77 \mathrm{a}$ \\
\hline $\mathrm{MeJa}+\mathrm{NaCl}$ & $844.40 \pm 7.08 b$ & $2273.53 \pm 0.60 a$ & $117.78 \pm 1.09 a$ \\
\hline
\end{tabular}

\subsection{Chlorophylls and Carotenoids}

Chlorophyll a content was higher in MeJa-treated plants compared to the rest of treatments (Table 7), while a reduction in chlorophyll $\mathrm{b}$ was induced by MeJa application in both MeJa and $\mathrm{NaCl}+\mathrm{MeJa}$ treatments. Finally, carotenoids increased in MeJa treatment, but they remained unmodified in $\mathrm{NaCl}+$ MeJa.

Table 7. The content of chlorophyll a $\left(\mathrm{mg} \mathrm{kg}^{-1} \mathrm{DW}\right)$, chlorophyll b ( $\left.\mathrm{mgk}^{-1} \mathrm{DW}\right)$, and carotenoids (C) $\left(\mathrm{mg} \mathrm{kg}^{-1} \mathrm{DW}\right)$ in the leaf tissues of $C$. maritimum under the different treatments (Control1, Control2, $\mathrm{NaCl}, \mathrm{MeJa}, \mathrm{NaCl}+\mathrm{MeJa}),(n=10)$. Columns with different letters $(\mathrm{a}, \mathrm{b}, \mathrm{c}, \mathrm{d}, \mathrm{e})$ for each variable differ significantly according to Tukey's test $(p<0.05)$.

\begin{tabular}{ccccc}
\hline Treatments & $\begin{array}{c}\text { Ch a } \mathbf{~ ( m g ~ k g ~}^{-1} \\
\text { DW) }\end{array}$ & $\begin{array}{c}\text { Ch b } \mathbf{~ ( m g ~ k g ~}^{-1} \\
\text { DW) }\end{array}$ & $\begin{array}{c}\text { C (mg kg } \\
\text { DW) }\end{array}$ & Ch a/Ch b \\
\hline Control1 & $12.68 \pm 0.05 \mathrm{~b}$ & $7.51 \pm 0.40 \mathrm{a}$ & $2.43 \pm 0.09 \mathrm{~b}$ & $1.69 \pm 0.00 \mathrm{a}$ \\
Control2 & $15.41 \pm 0.23 \mathrm{~b}$ & $7.92 \pm 0.03 \mathrm{a}$ & $2.62 \pm 0.03 \mathrm{~b}$ & $1.94 \pm 0.00 \mathrm{c}$ \\
$\mathrm{NaCl}$ & $16.13 \pm 0.45 \mathrm{~b}$ & $8.85 \pm 0.29 \mathrm{a}$ & $2.86 \pm 0.21 \mathrm{~b}$ & $1.82 \pm 0.00 \mathrm{~b}$ \\
$\mathrm{MeJa}$ & $17.77 \pm 0.05 \mathrm{a}$ & $4.98 \pm 0.03 \mathrm{~b}$ & $4.25 \pm 0.00 \mathrm{a}$ & $3.56 \pm 0.00 \mathrm{e}$ \\
$\mathrm{NaCl}+\mathrm{MeJa}$ & $14.22 \pm 0.01 \mathrm{~b}$ & $4.24 \pm 0.08 \mathrm{~b}$ & $3.40 \pm 0.01 \mathrm{ab}$ & $3.35 \pm 0.00 \mathrm{~d}$ \\
\hline
\end{tabular}

\section{Discussion}

Salinity is an important problem that affects the growth and development of plants. Halophytes have been suggested as new crops for foodstuffs due to their development of different strategies to cope with salt stress [34,35,51]. In C. maritimum, physiological aspects of salt response were determined via salt $(\mathrm{NaCl})$ concentrations ranging from 0 to $300 \mathrm{mM}$ [52]. The results showed almost a 50\% reduction in the leaf dry weight at $150 \mathrm{mM}$ $\mathrm{NaCl}$ with respect to $0 \mathrm{mM}$. Moreover, in our work, a $150 \mathrm{mM} \mathrm{NaCl}$ treatment reduced leaf biomass of C. maritimum plants grown in a hydroponic floating system. However, the studied genotype can be considered as a facultative halophyte since the plants did not need salt to grow and the total plant DW increased under salinity. Leaf plant biomass reduction was in consonance with previous reports, where C. maritimum plants irrigated with $\mathrm{NaCl}$, from 100 to $500 \mathrm{mM} \mathrm{NaCl}$, reduced their shoot fresh and dry weights [52], even at moderate $(150-170 \mathrm{mM}) \mathrm{NaCl}$ concentrations $[52,53]$.

By contrast, root length, root area, and root volume were significantly higher after $\mathrm{NaCl}$ treatment in comparison to the rest of treatments. The MeJa only application reduced C. maritimum total biomass. It was reported that exogenous application of MeJA decreased photosynthesis [54] and inhibited plant growth [55]. However, MeJa addition contributed to minimalize the adverse effect of salinity on shoot biomass (Figure 1). Although it is known that MeJa alleviated the salt stress in glycophyte plants such as rice (Oryza sativa L.) [56] and B. napus [57], less is known about the addition of MeJa under salinity in halophyte plants. In Limonium bicolor (Bunge) Kuntze, exogenous $0.03 \mathrm{mM}$ 
jasmonic acid (JA) improved plants biomass after $300 \mathrm{mM} \mathrm{NaCl}$ addition, demonstrating that the most relevant physiological parameter involved in plant growth and salt tolerance by MeJa was the net photosynthesis [58], but other mechanisms of MeJa for salt stress alleviation cannot be ruled out in C. maritimum plants. Thus, changes in trichome and cuticle composition and thickness, and stomatal density are induced by MeJa [59] and may protect plants from salinity through the observed increase in the leaf hydraulic content as Na concentration increased, but further research is needed. Considering the recent interest in this halophyte as a traditional agri-food product, increasing the edible plant parts by MeJa under salinity has given rise to great interest.

It is well known that salinity may restrict the mineral uptake by the roots [60]. This was the case of several cations as $\mathrm{Ca}^{2+}$ and $\mathrm{K}^{+}$, demonstrating that limitation in the nutrient uptake may contribute to the general decrease in aerial growth. Ben-Hamed et al. [34] found a gradual reduction of $\mathrm{Ca}^{2+}$ and $\mathrm{K}^{+}$ions with increasing salinity, the decrease being higher in the leaves and stems when compared to the root. MeJa recovered $\mathrm{Ca}^{2+}$ and $\mathrm{K}^{+}$ ions levels in the leaves of the plants treated with salinity, emphasizing the important role of MeJa on K homeostasis under salt stress [61,62] in C. maritimum plants.

It was shown that MeJa may increase root hydraulic conductance in maize [63] and tomato plants [64]. Therefore, a higher water uptake may result in higher $\mathrm{Ca}^{2+}$ and $\mathrm{K}^{+}$ uptake and translocation. This effect of MeJa on ion transport in $\mathrm{NaCl}+\mathrm{MeJa}$ plants may explain the recovery of $\mathrm{Ca}^{2+}$ and $\mathrm{K}^{+}$ions and the unmodified $\mathrm{K} / \mathrm{Na}$ ratio compared to $\mathrm{NaCl}$-treated plants, since it is well established that there are negative effects from salt stress on the coupled water and ion transport [65]. Moreover, these Ca and K increases may add nutritional value to the leaf mineral content of the plants.

In carrot plants, MeJa-induced changes improved mineral balance under salt stress through a reduction in $\mathrm{Na}^{+}$and $\mathrm{Cl}^{-}$accumulation [66]. However, in our experiment, $\mathrm{Na}^{+}$and $\mathrm{Cl}^{-}$content were similar in the leaves of $\mathrm{NaCl}$ and $\mathrm{MeJa}+\mathrm{NaCl}$ treated plants, indicating that the effect of MeJa in saline ions uptake is species-dependent. In addition, a high correlation (0.926) between the leaf hydric content and $\mathrm{Na}$ accumulation was found (Figure 2). Osmolyte concentration in the leaves of the sea fennel was significantly raised with increased time periods and $\mathrm{NaCl}$ concentrations [40] and, therefore, leaf succulence could also be increased, contributing as a mechanism to cope with salt stress in our plants.

As a facultative halophyte, $C$. maritimum may tolerate $\mathrm{Na}^{+}$and $\mathrm{Cl}^{-}$concentrations that could be compartmentalized in the vacuole [51]. In tomato plants, a higher $\mathrm{Cl}^{-}$content induced the reduction of nitrate uptake [67]. By contrast, in sea fennel plants the levels of $\mathrm{NO}_{3}{ }^{-}$were similar in all treatments, indicating the lack of competence of $\mathrm{Cl}^{-}$concerning $\mathrm{NO}_{3}{ }^{-}$translocation, but $\mathrm{NaCl}$ treatment reduced $\mathrm{NO}_{2}{ }^{-}$content. MeJa addition restored the level of $\mathrm{NO}_{2}{ }^{-}$as well as increased the $\mathrm{NH}_{4}{ }^{+}$levels of Control1 and Control2 plants. This effect of MeJa was described previously for Vaccinium myrtillus L. plants, where MeJa up-regulated genes were involved in nitrite transport and metabolism [68]. There is a lack of literature on the effect of MeJa on halophytes, to the best of our knowledge. The existing study reports point to the combined effect of MeJa to salinity on C. maritimum plants, but similar gene-regulation in nitrogen metabolism could occur. In any case, from a nutritional point of view, the level of nitrate ions was lower than those of other baby leaf crops such as lettuce (from 700 to $1264 \mathrm{mg} \mathrm{kg}^{-1} \mathrm{FW}$ ), spinach (from 700 to $2013 \mathrm{mg} \mathrm{kg}^{-1} \mathrm{FW}$ ), kale (from 600 to $1181 \mathrm{mg} \mathrm{kg}^{-1} \mathrm{FW}$ ), and chard (from 900 to $1024 \mathrm{mg} \mathrm{kg}^{-1} \mathrm{FW}$ ) [69]. Similarly, low levels of nitrite were detected in lettuce and spinach (up to $197.5 \mathrm{mg} \mathrm{kg}^{-1}$ ) [70]. The acceptable daily intake (ADI) for nitrate, as determined by the Scientific Committee on Food (SCF), was 0 to $3.7 \mathrm{mg} / \mathrm{kg}$ body weight per day. This means that if the average adult consumes approximately $400 \mathrm{~g}$ of various vegetables daily, the intake of nitrate is around $222.0 \mathrm{mg} /$ day (FAO/WHO 2013). In this sense, the consumption of $100 \mathrm{gr}$ of C. maritimum baby leaf plants do not reach the ADI for nitrate and nitrite.

In studies with halophytes, fatty acid unsaturation is intrinsically high, considering a mechanism of halophytes to high salt stress adaptation [71]. According to this, the higher content of individual fatty acids in this plant was found for linoleic and linolenic acids. 
However, in spite of being a halophyte, the C. maritimum fatty acids content increased under salinity conditions, indicating a certain lipid metabolism adaptation, although the DBI remained unmodified. Ben Hamed et al. [72] found that in C. maritimum plants salinity decreased the percentage of unsaturated fatty acids (C18:3) and increased the percentage of unsaturated fatty acids (C18:2). In another halophyte, Cakile maritima Scop., no change in the unsaturation level was observed under salinity as an indication of plant adaptation to salt stress [71]. These differences may reflect the distinct nature of halophytes and their threshold for salt sensibility. In our experiment we observed that $C$. maritimum plants membrane fluidity properties, reflected in the unsaturation degree, seem to be stable under salinity, indicating a genotype adaptation. Moreover, linolenic acid was related to membrane fluidity properties [73], and the reduction of the percentage of this fatty acid from 38 to $34.8 \%$ in NaCl-treated plants after MeJa addition may indicate the amelioration of MeJa considering the salt effect on lipid membrane properties. From a nutritional point of view, the analysed treatments characterise these plants as a rich source of essential fatty acids (18:2v6 and 18:3v3), which are involved in human metabolism in consonance with previous results [74], but reductions of omega 3 acids by MeJa spraying to saline plants also have to be considered.

Moreover, a high content of phenolic compounds has been determined in the aerial part of $C$. maritimum plants when compared to other crops. Other vegetables such as caraway (770 GA mg kg ${ }^{-1} \mathrm{FW}$ ), chives (567 GA mg kg ${ }^{-1} \mathrm{FW}$ ), cowpea (717 GA mg kg-1 FW), pak choi (820 GA mg kg $\left.{ }^{-1} \mathrm{FW}\right)$, and perilla leaf (687 $\mathrm{GA} \mathrm{mg} \mathrm{kg}^{-1} \mathrm{FW}$ ) [75] showed lower levels of total phenolic compounds than the C. maritimum plants grown in our experiment. Thus, although both saline treatments, $\mathrm{NaCl}$ and $\mathrm{NaCl}+\mathrm{MeJa}$, decreased the content of the total phenolic compounds in terms of Control1 and Control2, the plants maintained their antioxidant properties. However, in sweet basil (Ocimum basilicum L.) MeJa alleviated the effects of salinity stress on phenolic compounds [59,76]. Moreover, in Lepidium sativum L., MeJa acted as a signalling molecule to enhance antioxidant pool and protect plants against injuries caused by $\mathrm{Cu}$ toxicity [77]. Del Amor and Cuadra-Crespo [78] observed that after foliar application of MeJa, broccoli plants enhanced salt tolerance effects through growth, photosynthesis, and root respiration increase. These results demonstrated that exogenous JA may be involved in the defence not only during biotic stress, but also during salt stress.

In our plants the total phenolic compounds and antioxidant capacity remained unmodified by the MeJa only addition. Phenolic plant production also depends on the stress intensity and duration. Thus, in our experiment, both $150 \mathrm{mM} \mathrm{NaCl}$ and MeJa induced a flavonoid increase rather than total phenolic compounds. A similar result was observed in Hibiscus sabdariffa L. seedlings, where flavonoids increased after MeJa application at $50 \mathrm{mM}$ $\mathrm{NaCl}$ [79]. The role of JAs in the antioxidant response of halophytic plants to salt stress is still poorly understood and more research is required.

Finally, the effects of salinity stress on chlorophyll a, chlorophyll b and carotenoid were depreciable in comparison with Control1 and Control2. A similar situation was observed in maize (Zea maize L.) plants [80]. However, in different Brassica oleracea L. varieties, seed priming with distinct MeJa and JA concentrations had an increase or decrease in the Chla/b ratio, indicating the dose and genotypic dependence of MeJa's effect on photosynthesis and PSII protein complex [81]. As the effect of MeJa on the photosynthetic machinery of the halophytes has not yet been studied, new experimentation is required.

\section{Conclusions}

In summary, MeJa alleviated the adverse effects of salinity on shoot growth, improving edible biomass after $\mathrm{NaCl}$ addition in sea fennel plants. This resulted in an increased ratio of the edible parts of this crop. Moreover, MeJa spraying favoured an enhanced $\mathrm{Ca}^{2+}$ and $\mathrm{K}^{+}$uptake under salt stress, but it could not prevent $\mathrm{Na}^{+}$translocation to the aerial part. Thus, the beneficial effect of MeJa on plant growth was not related to the $\mathrm{Na}^{+}$toxicity and seemed to be in consonance with the transport of other ions. In fact, the strong relation 
between the leaf hydric content and leaf Na levels suggest leaf succulence and osmolyte accumulation as mechanisms to cope with salt stress. From a nutritional point of view, the content of fatty acids was high in C. maritimum baby leaf, with linolenic and linoleic acids being the main fatty acids. However, reductions in omega 3 acids by MeJa spraying under salinity conditions must be considered when MeJa was applied to reduce adverse effects of salt stress on aerial growth. All the above results indicate that a hydroponic floating system was a suitable method for growing C. maritimum baby leaf, where the addition of Meja spraying to saline seedlings may alleviate adverse effects of salt stress, does not affect the total phenolic compounds and antioxidant capacity of the plants, but increases total carotenoids and minerals.

Author Contributions: Conceptualization, J.A.F., C.E.-G., and M.d.C.M.-B.; methodology, M.H.L., H.V., and A.G.; validation, Y.T. and H.V.; formal analysis, A.G. and M.H.L.; data curation, J.A.F. and M.d.C.M.-B.; writing—original draft preparation, M.d.C.M.-B.; writing—review and editing, J.A.F., C.E.-G., A.G., and Y.T.; visualization, J.A.F., C.E.-G., and M.d.C.M.-B.; supervision, M.d.C.M.-B., J.A.F. and Y.T.; project administration, C.E.-G. and J.A.F.; funding acquisition, C.E.-G. and J.A.F. All authors have read and agreed to the published version of the manuscript.

Funding: This research was conducted in the framework of a research program ACI-B sponsored by UPCT.

Institutional Review Board Statement: Not applicable.

Informed Consent Statement: Not applicable.

Data Availability Statement: The datasets generated for this study are available upon request to the corresponding author.

Conflicts of Interest: The authors declare no conflict of interest.

\section{References}

1. Verzeletti, C.; Maes, L.; Santinello, M.; Vereecken, C.A. Food-related family lifestyle associated with fruit and vegetable consumption among young adolescents in Belgium Flanders and the Veneto Region of Italy. Appetite 2010, 54, 394-397. [CrossRef]

2. Grosso, G.; Marventano, S.; Nolfo, F.; Rametta, S.; Bandini, L.; Ferranti, R.; Bonomo, M.C.; Matalone, M.; Galvano, F.; Mistretta, A. Personal eating, lifestyle, and family-related behaviors correlate with fruit and vegetable consumption in adolescents living in Sicily, Southern Italy. Int. J. Vitam. Nutr. Res. 2013, 83, 355-366. [CrossRef]

3. Ngozika, E.; Obeagu, E.A. Review on Fast Foods and Family Lifestyle. Int. J. Curr. Res. Biol. Med. 2018, 3, 26-30. [CrossRef]

4. Da Silva Santos, J.M. Minimally Processed Baby Leaf Vegetables: Phytonutrient Characterization and Nutritional Stability. Ph.D. Thesis, Universidade do Porto, Porto, Portugal, 2014; p. 173.

5. Saini, R.K.; Ko, E.Y.; Keum, Y.S. Minimally processed ready-to-eat baby-leaf vegetables: Production, processing, storage, microbial safety and nutritional potential. Food Rev. Int. 2017, 33, 644-663. [CrossRef]

6. Gil, M.I.; Tudela, J.A.; Martínez-Sánchez, A.; Luna, M.C. Harvest maturity indicators of leafy vegetables. Stewart Postharvest Rev. 2012, 8, 1-9. [CrossRef]

7. Aires, A.; Marques, E.; Carvalho, R.; Rosa, E.A.S.; Saavedra, M.J. Evaluation of biological value and appraisal of polyphenols and glucosinolates from organic baby-leaf salads as antioxidants and antimicrobials against important human pathogenic bacteria. Molecules 2013, 18, 4651-4668. [CrossRef] [PubMed]

8. Aires, A.; Carvalho, R.; Rosa, E.A.S.; Saavedra, M.J. Phytochemical characterization and antioxidant properties of baby-leaf watercress produced under organic production system. CyTA J. Food 2013, 11, 343-351. [CrossRef]

9. Santos, J.; Oliva-Teles, M.T.; Delerue-Matos, C.; Oliveira, M.B.P.P. Multi-elemental analysis of ready-to-eat "baby leaf" vegetables using microwave digestion and high-resolution continuum source atomic absorption spectrometry. Food Chem. 2014, 151, 311-316. [CrossRef]

10. Sundriyal, M.; Sundriyal, R.C.; Url, S. Wild edible plants of the Sikkim Himalaya: Nutritive values of selected species. Econ. Bot. 2001, 55, 377-390. [CrossRef]

11. Giménez, A.; Fernández, J.A.; Pascual, J.A.; Ros, M.; López-Serrano, M.; Egea-Gilabert, C. An Agroindustrial Compost as Alternative to Peat for Production of Baby Leaf Red Lettuce in a Floating System. Sci. Hortic. 2019, 246, 907-915. [CrossRef]

12. Colla, G.; Rouphael, Y.; Cardarelli, M.; Svecova, E.; Rea, E.; Lucini, L. Effects of saline stress on mineral composition, phenolic acids and flavonoids in leaves of artichoke and cardoon genotypes grown in floating system. J. Sci. Food Agric. 2013, 93, 1119-1127. [CrossRef]

13. Borgognone, D.; Cardarelli, M.; Lucini, L.; Colla, G. Does $\mathrm{CaCl}_{2}$ play a role in improving biomass yield and quality of cardoon grown in a floating system under saline conditions? HortScience 2014, 49, 1523-1528. [CrossRef] 
14. Rufí-Salís, M.; Parada, F.; Arcas-Pliz, V.; Petit-Boix, A.; Villalba, G.; Gabarrell, X. Closed-loop crop cascade to optimizze nutrient flows and grow low-impact vegetables in cites. Front. Plant Sci. 2020, 11, 566550. [CrossRef] [PubMed]

15. D'Imperio, M.; Renna, M.; Cardinali, A.; Buttaro, D.; Serio, F.; Santamaria, P. Calcium biofortification and Bioaccessibility in Soilless "Baby Leaf" Vegetable Production. Food Chem. 2016, 213, 149-156. [CrossRef]

16. Renna, M. Reviewing the Prospects of Sea Fennel (Crithmum maritimum L.) as Emerging Vegetable Crop. Plants $2018,7,92$. [CrossRef]

17. Riddle, J. Folk Tradition and Folk Medicine: Recognition of Drugs in Classical Antiquity. Pharm. Hist. 2013, 55, 64-87. [PubMed]

18. Mekinić, I.G.; Blažević, I.; Mudnić, I.; Burčul, F.; Grga, M.; Skroza, D.; Jerčić, I.; Ljubenkov, I.; Boban, M.; Miloš, M.; et al. Sea fennel (Crithmum maritimum L.): Phytochemical profile, antioxidative, cholinesterase inhibitory and vasodilatory activity. J. Food Sci. Technol. 2016, 53, 3104-3112. [CrossRef]

19. Pavela, R.; Maggi, F.; Lupidi, G.; Cianfaglione, K.; Dauvergne, X.; Bruno, M.; Benelli, G. Efficacy of sea fennel (Crithmum maritimum L., Apiaceae) essential oils against Culex quinquefasciatus Say and Spodoptera littoralis (Boisd.). Ind. Crop. Prod. 2017, 109, 603-610. [CrossRef]

20. Franke, W. Vitamin C in sea fennel (Crithmum maritimum), an edible wild plant. Econ. Bot. 1982, 36, 163-165. [CrossRef]

21. Males, Z.; Zuntar, I.; Nigovic, B.; Plazibat, M.; Vundac, V.B. Quantitative analysis of the polyphenols of the aerial parts of rock samphire-Crithmum maritimum L. Acta Pharm. 2003, 53, 139-144. [PubMed]

22. Meot-Duros, L.; Magné, C. Antioxidant activity and phenol content of Crithmum maritimum L. leaves. Plant Physiol. Biochem. 2009, 47, 37-41. [CrossRef] [PubMed]

23. Jallali, I.; Megdiche, W.; M'Hamdi, B.; Oueslati, S.; Smaoui, A.; Abdelly, C.; Ksouri, R. Changes in phenolic composition and antioxidant activities of the edible halophyte Crithmum maritimum L. with physiological stage and extraction method. Acta Physiol. Plant. 2012, 34, 1451-1459. [CrossRef]

24. Bartnik, M.; Wierzchowska-Renke, K.; Głowniak, P.; Głowniak, K. Phenolic acids in Crithmum maritimum L. (Apiaceae) after Tytanit fertilization. Acta Soc. Bot. Pol. 2017, 86, 3560. [CrossRef]

25. Zafeiropoulou, V.; Tomou, E.M.; Ioannidou, O.; Karioti, A.; Skaltsa, H. Sea fennel: Phytochemical analysis of Greek wild and cultivated Crithmum maritimum L. populations, based on HPLC-PDA-MS and NMR methods. J. Pharmacogn. Phytochem. 2020, 9 , 998-1004. [CrossRef]

26. Nabet, N.; Boudries, H.; Chougui, N.; Loupassaki, S.; Souagui, S.; Burló, F.; Hernández, F.; Carbonell-Barrachina, A.A.; Madani, K.; Larbat, R. Biological activities and secondary compound composition from Crithmum maritimum aerial parts. Int. J. Food Prop. 2017, 20, 1843-1855. [CrossRef]

27. Marchioni-Ortu, A.; Bocchieri, E. A study of the germination responses of a Sardinian population of sea fennel (Crithmum maritimum). Can. J. Bot. 1984, 62, 1832-1835. [CrossRef]

28. Atia, A.; Ben Hamed, K.; Debez, A.; Abdelly, C. Salt and seawater effects on the germination of Crithmum maritimum. In Biosalite Agriculture and Salinity Tolerance in Plant; Birkhäuser: Basel, Switzerland, 2006; pp. 29-33. [CrossRef]

29. Atia, A.; Debez, A.; Barhoumi, Z.; Smaoui, A.; Abdelly, C. ABA, GA3, and nitrate may control seed germination of Crithmum maritimum (Apiaceae) under saline conditions. Comptes Rendus Biol. 2009, 332, 704-710. [CrossRef]

30. Meot-Duros, L.; Magné, C. Effect of salinity and chemical factors on seed germination in the halophyte Crithmum maritimum L. Plant Soil 2008, 313, 83-87. [CrossRef]

31. Nimac, A.; Lazarevic, B.; Petek, M.; Vidak, M.; Satovic, Z.; Carovic-Stanko, K. Effects of Salinity and Seed Priming on Germination of Sea Fennel (Crithmum maritimum L.). Agric. Conspec. Sci. 2018, 83, 181-185.

32. Montesano, F.F.; Gattulo, C.E.; Parente, A.; Terzano, R.; Renna, M. Cultivation of Potted Sea Fennel, an Emerging Mediterranean Halophyte, Using a Renewable Seaweed-Based Material as a Peat Substitute. Agriculture 2018, 8, 96. [CrossRef]

33. Grigoriadou, K.; Maloupa, E. Micropropagation and salt tolerance of in vitro grown Crithmum maritimum L. Plant Cell Tissue Organ Cult. 2008, 94, 209-217. [CrossRef]

34. Ben Hamed, K.; Castagna, A.; Salem, E.; Ranieri, A.; Abdelly, C. Sea Fennel (Crithmum maritimum L.) under Salinity Conditions: A Comparison of Leaf and Root Antioxidant Responses. Plant Growth Regul. 2007, 53, 185-194. [CrossRef]

35. Amor, N.B.; Hamed, K.B.; Debez, A.; Grignon, C.; Abdelly, C. Physiological and antioxidant responses of the perennial halophyte Crithmum maritimum to salinity. Plant Sci. 2005, 168, 889-899. [CrossRef]

36. Zarrouk, M.; El Almi, H.; Ben Youssef, N.; Sleimi, N.; Smaoui, A.; Ben Miled, D.; Abdelly, C. Lipid composition of seeds of local halophytes: Cakile maritima, Zygophyllum album and Crithmum maritimum. In Cash Crop Halophytes: Recent Studies: Tasks for Vegetation Science; Lieth, H., Mochtchenko, M., Eds.; Springer: Dordrecht, The Netherlands, 2003; Volume 38. [CrossRef]

37. Bahmani, K.; Darbandi, A.I.; Alfekaiki, D.F.; Sticklen, M. Phytochemical diversity of fennel landraces from various growth types and origins. Agron. Res. 2016, 14, 1530-1547.

38. Wasternack, C.; Song, S. Jasmonates: Biosynthesis, metabolism, and signaling by proteins activating and repressing transcription. J. Exp. Bot. 2017, 68, 1303-1321. [CrossRef]

39. Faghih, S.; Ghobadi, C.; Zarei, A. Response of strawberry plant cv. 'Camarosa' to Salicylic Acid and Methyl Jasmonate application under salt stress condition. J. Plant Growth Regul. 2017, 36, 651-659. [CrossRef]

40. Hassini, I.; Martinez-Ballesta, M.C.; Boughanmi, N.; Moreno, D.A.; Carvajal, M. Improvement of broccoli sprouts (Brassica oleracea L. var. italica) growth and quality by $\mathrm{KCl}$ seed priming and methyl jasmonate under salinity stress. Sci. Hortic. 2017, 226, 141-151. [CrossRef] 
41. Manan, A.; Ayyub, C.M.; Pervez, M.A.; Ahmad, R. Methyl Jasmonate brings about resistance against salinity stressed tomato plants by altering biochemical and physiological processes. Pak. J. Agric. Sci. 2016, 53, 35-41. [CrossRef]

42. Pérez-Balibrea, S.; Moreno, D.A.; García-Viguera, C. Improving the Phytochemical Composition of Broccoli Sprouts by Elicitation. Food Chem. 2011, 129, 35-44. [CrossRef]

43. Xie, Q.; Yan, F.; Hu, Z.; Wei, S.; Lai, J.; Chen, G. Accumulation of anthocyanin and its associated gene expression in purple tumorous stem mustard (Brassica juncea Var. tumida Tsen et Lee) sprouts when exposed to light, dark, sugar, and Methyl Jasmonate. J. Agric. Food Chem. 2019, 67, 856-866. [CrossRef]

44. Lara, L.J.; Egea-Gilabert, C.; Niñirola, D.; Conesa, E.; Fernández, J.A. Effect of Aeration of the Nutrient Solution on the Growth and Quality of Purslane (Portulaca Oleracea). J. Hortic. Sci. Biotechnol. 2011, 86, 603-610. [CrossRef]

45. O'Fallon, J.V.; Busboom, J.R.; Nelson, M.L.; Gaskins, C.T. A direct method for fatty acid methyl ester synthesis: Application to wet meat tissues, oils, and feedstuffs. J. Anim. Sci. 2007, 85, 1511-1521. [CrossRef]

46. Lichtenthaler, H.K.; Buschmann, C. Chlorophylls and Carotenoids: Measurement and Characterization by UV-VIS Spectroscopy. Curr. Protoc. Food Anal. Chem. 2001, 1, F4.3.1-F4.3.8. [CrossRef]

47. Meda, A.; Lamien, C.E.; Romito, M.; Millogo, J.; Nacoulma, O.G. Determination of the total phenolic, flavonoid and proline contents in Burkina Fasan honey, as well as their radical scavenging avtivity. Food Chem. 2005, 571-577. [CrossRef]

48. Everette, J.D.; Brayant, Q.M.; Green, A.M.; Abbey, Y.A.; Wangila, G.W.; Walker, R.B. Through study of reactivity of various compound classes toward the Folin-Ciocalteu reagent. J. Agric. Food Chem. 2010, 58, 8139-8144. [CrossRef]

49. Brand-Williams, W.; Cuvelier, M.E.; Berset, C. Use of free radical method to evaluate antioxidant activity. Lebensm. Wiss. Technol. 1995, 28, 25-30. [CrossRef]

50. Pérez-Tortosa, V.; López-Orenes, A.; Martínez-Pérez, A.; Ferrer, M.A.; Calderón, A.A. Antioxidant activity and rosmarinic acid changes in salicylic acid-treated Thymus membranaceus shoot. Food Chem. 2012, 130, 362-369. [CrossRef]

51. Aslam, R.; Bostan, N.; Maria, M.; Safdar, W. A Critical Review on Halophytes: Salt Tolerant Plants. J. Med. Plants Res. 2011, 5, 7108-7118. [CrossRef]

52. Ben Hamed, K.; Debez, A.; Chibani, F.; Abdelly, C. Salt Response of Crithmum maritimum, an Oleagineous Halophyte. Trop. Ecol. 2004, 45, 151-159.

53. Hamdani, F.; Derridj, A.; Rogers, H.J. Diverse salinity responses in Crithmum maritimum tissues at different salinities over time. J. Soil Sci. Plant Nutr. 2017, 17, 716-734. [CrossRef]

54. Attaran, F.; Mayor, I.T.; Cruz, J.A.; Rosa, B.A.; Koo, A.J.K.; Chen, J.; Kramer, D.M.; He, S.Y.; Howe, G.A. Temporal dynamics of growth and photosynthesis suppression in response to jasmonate signalling. Plant Physiol. 2014, 165, 1302-1314. [CrossRef]

55. Shyu, C.; Brutnell, T.P. Growth deference balance in grass biomass production: The role of jasmonates. J. Exp. Bot. 2015, 66, 4165-4176. [CrossRef]

56. Mahmud, S.; Sharmin, S.; Chowdhury, B.L.D.; Hossain, M.A.; Bhuiyan, M.J.H. Mitigation of Salt Stress in Rice Plant at Germination Stage by Using Methyl Jasmonate. Asian J. Med. Biol. Res. 2016, 2, 74-81. [CrossRef]

57. Comparot, S.M.; Graham, C.M.; Reid, D.M. Methyl Jasmonate Elicits a Differential Antioxidant Response in Light-and DarkGrown Canola (Brassica napus) Roots and Shoots. Plant Growth Regul. 2002, 38, 21-30. [CrossRef]

58. Yuan, F.; Liang, X.; Li, Y.; Yin, S.; Wang, B. Methyl Jasmonate Improves Tolerance to High Salt Stress in the Recretohalophyte Limonium bicolor. Funct. Plant Biol. 2019, 46, 82-92. [CrossRef]

59. Li, C.; Wang, P.; Menzles, N.; Lombi, E. Effects of methyljasmonate on plant growth and leaf properties. J. Plant Nutr. Soil Sci. 2018, 181, 409-418. [CrossRef]

60. Hamed, K.B.; Messedi, D.; Ranieri, A.; Abdelly, C. Diversity in the response of two potential halophytes (Batis maritima and Crithmum maritimum) to salt stress. In Biosaline Agriculture and High Salinity Tolerance; Birkhäuser: Basel, Switzland, 2008; pp. 71-80. [CrossRef]

61. Evans, N.H. Modulation of guard cell plasma membrane potassium currents by methyl jasmonate. Plant Physiol. 2003, 131, 8-11. [CrossRef] [PubMed]

62. Armengaud, P.; Breitling, R.; Amtmann, A. The Potassium-Dependent Transcriptome of Arabidopsis Reveals a Prominent Role of Jasmonic Acid in Nutrient Signaling. Plant Physiol. 2004, 136, 2556-2576. [CrossRef]

63. Battal, P.; Erez, M.E.; Turker, M.; Berber, I. Molecular and Physiological Changes in Maize (Zea Mays) Induced by Exogenous NAA, ABA and MeJa during Cold Stress. Ann. Bot. Fenn. 2008, 45, 173-185. [CrossRef]

64. Sánchez-Romera, B.; Ruiz-Lozano, J.M.; Li, G.; Luu, D.T.; Martínez-Ballesta, M.D.C.; Carvajal, M.; Zamarreño, A.M.; García-Mina, J.M.; Maurel, C.; Aroca, R. Enhancement of Root Hydraulic Conductivity by Methyl Jasmonate and the Role of Calcium and Abscisic Acid in This Process. Plant Cell Environ. 2014, 37, 995-1008. [CrossRef] [PubMed]

65. Djanaguiraman, M.; Pasad, P.V.V. Effects of salinity on ion transport, water relations and oxidative damage. In Ecophysiology and Response of Plants under Salt Stress; Springer: New York, NY, USA, 2012; pp. 89-114. [CrossRef]

66. Smoleń, S.; Lukasiewicz, A.; Klimek-Chodacka, M.; Baranski, R. Effect of Soil Salinity and Foliar Application of Jasmonic Acid on Mineral Balance of Carrot Plants Tolerant and Sensitive to Salt Stress. Agronomy 2020, 10, 659. [CrossRef]

67. Manaa, A.; Ben Ahmed, H.; Valot, B.; Bouchet, J.P.; Aschi-Smiti, S.; Causse, M.; Faurobert, M. Salt and Genotype Impact on Plant Physiology and Root Proteome Variations in Tomato. J. Exp. Bot. 2011, 62, 2797-2813. [CrossRef] [PubMed]

68. Benevenuto, R.F.; Seldal, T.; Hegland, S.J.; Rodriguez-Saona, C.; Kawash, J.; Polashock, J. Transcriptional Profiling of Methyl Jasmonate-Induced Defense Responses in Bilberry (Vaccinium myrtillus L.). BMC Plant Biol. 2019, 19, 70. [CrossRef] [PubMed] 
69. Brkić, D.; Bošnir, J.; Bevardi, M.; Bošković, A.G.; Miloš, S.; Lasić, D.; Krivohlavek, A.; Racz, A.; Ćuić, A.M.; Trstenjak, N.U. Nitrate in leafy green vegetables and estimated intake. Afr. J. Tradit. Complement. Altern. Med. 2017, 14, 31-41. [CrossRef]

70. Iammarino, M.; Di Taranto, A.; Cristino, M. Monitoring of Nitrites and Nitrates Levels in Leafy Vegetables (Spinach and Lettuce): A Contribution to Risk Assessment. J. Sci. Food Agric. 2014, 94, 773-778. [CrossRef]

71. Chalbi, N.; Martínez-Ballesta, M.C.; Youssef, N.B.; Carvajal, M. Intrinsic stability of Brassicaceae plasma membrane in relation to changes in proteins and lipids as a response to salinity. J. Plant Physiol. 2015, 175, 148-156. [CrossRef]

72. Ben Hamed, K.; Ben Youssef, N.; Ranieri, A.; Zarrouk, M.; Abdelly, C. Changes in content and fatty acid profiles of total lipids and sulfolipids in the halophyte Crithmum maritimum under salt stress. J. Plant Physiol. 2005, 162, 599-602. [CrossRef] [PubMed]

73. Moller, I.M.; Jensen, P.E.; Hansson, A. Oxidative modifications to cellular components in plants. Annu. Rev. Plant Biol. 2007, 58, 459-481. [CrossRef]

74. Guil-Guerrero, J.L.; Rodrñiguez-García, I. Lipids classes, fatty acids and carotenes of the leaves of six edible wild plants. Eur. Food Res. Technol. 1999, 209, 313-316. [CrossRef]

75. Deng, G.F.; Lin, X.; Xu, X.R.; Gao, L.L.; Xie, J.F.; Li, H.B. Antioxidant Capacities and Total Phenolic Contents of 56 Vegetables. J. Funct. Foods 2013, 5, 260-266. [CrossRef]

76. Kim, H.J.; Chen, F.; Wang, X.; Rajapakse, N.C. Effect of Methyl Jasmonate on Secondary Metabolites of Sweet Basil (Ocimum basilicum L.). J. Agric. Food Chem. 2006, 54, 2327-2332. [CrossRef] [PubMed]

77. Asadi Karam, E.; Asrar, Z.; Keramat, B. Effects of Methyl jasmonate pretreatment on phenolic compounds and PAL activity in Lepidium sativum L. subjected to copper toxicity. J. Plant Proc. Funct. 2014, 2, 89-96.

78. Del Amor, F.; Cuadra-Crespo, P. Alleviation of salinity stress in broccoli using foliar urea or methyl-jasmonate: Analysis of growth, gas exchange, and isotope composition. Plant Growth Regul. 2011, 63, 55-62. [CrossRef]

79. Sheyhakinia, S.; Bamary, Z.; Einali, A.; Valizadeh, J. The induction of salt stress tolerance by jasmonic acid treatment in roselle (Hibiscus sabdariffa L.) seedlings through enhancing antioxidant enzymes activity and metabolic changes. Biologia 2020, 75, 681-692. [CrossRef]

80. Abdelgawad, Z.A.; Khalafaallah, A.A.; Abdallah, M.M. Impact of Methyl Jasmonate on Antioxidant Activity and Some Biochemical Aspects of Maize Plant Grown under Water Stress Condition. Agric. Sci. 2014, 5, 1077-1088. [CrossRef]

81. Sirhindi, G.; Mushtaq, R.; Singh Gill, S.; Sharma, P.; Abd-Allah, E.F.; Ahmad, P. Jasmonic acid and methyl jasmonate modulate growth, photosynthetic activity and expression of photosystem II subunit genes in Brassica oleracea L. Sci. Rep. 2020, 10, 9322. [CrossRef] 